\title{
PENERAPAN VIDEO PROMOSI MENGGUNAKAN APLIKASI FILMORA PADA PETERNAK KAMBING DI MALANG
}

\author{
Mega Mirasaputri Cahyanti ${ }^{1}$, Widi Dewi Ruspitasari ${ }^{2}$, Pipit Rosita Andarsari ${ }^{3}$ \\ 1,2,3 Institut Teknologi dan Bisnis Asia Malang \\ Corresponding author* \\ Email : mega_mc@asia.ac.id (Mega Mirasaputri Cahyanti)*
}

Article History:

Received: 3-8-2020

Revised: $5-8-2020$

Accepted: 5-8-2020

Keywords :

\begin{abstract}
Setelah Covid-19 menyerang Indonesia, banyak bisnis perlu membangun strategi baru untuk menghadapi era normal baru. Termasuk setiap pemilik Peternakan Kambing di Malang, yang biasanya menjalankan proses jual beli secara tradisional. Strategi baru yang dapat dilakukan adalah melalui ekonomi kontak kurang, yang menggunakan internet. Ketika setiap pemilik peternakan kambing menjual produk mereka melalui internet, mereka juga tidak akan mendapatkan penghasilan biasa tetapi juga mendapatkan pembeli potensial yang lebih luas di luar Malang. Karena itu, Membuat Video Promosi menggunakan Kegiatan Pelatihan Filmora untuk Peternakan Kambing di Malang dilakukan dalam bentuk tutorial yang disampaikan langsung oleh pembicara. Dimana berdasarkan hasil pengabdian ini, setiap pemilik Peternakan Kambing di Malang sangat tertarik dan bersemangat untuk berpartisipasi dalam kegiatan serupa untuk pengembangan pengetahuan bisnis.

Goat Farm Malang, Making Video Promotion, Filmora
\end{abstract}

\section{Pendahuluan}

Masyarakat Malang patut berbangga dengan sederet potensi yang ada saat ini. Selain keindahan dan kekayaan alam yang tersebar di beberapa wilayah, daerah yang mempunyai slogan The Heart of East Java ini juga memiliki potensi unggul dibidang peternakan. 
Salah satunya dalam mengelola hewan ternak kambing. Hingga saat ini, tercatat ada ratusan ribu populasi kambing yang tersebar di beberapa wilayah. Capaian ini membuat Kabupaten Malang menjadi "kiblat" peternak kambing di Jawa Timur.

Kabupaten Malang dianggap sebagai sentra kambing terbaik di Jawa Timur. Kini populasi kambing tercatat mencapai sekitar 253 ribu ekor (Lupito, 2019). Harga rumput yang tinggi dan biaya operasional untuk memberi pakan hewan ternak membuat para peternak, harus memutar otak. Permasalah tersebut diperparah dengan adanya pandemic Covid 19 yang menimpa hampir semua para pebisnis di seluruh Indonesia, termasuk para peternak kambing yang ada di Malang. Sehingga perlu adanya strategi baru yang dijalankan oleh para peternak di Kota Malang untuk dapat menutupi biaya operasionalnya dan tetap mendapatkan keuntungan.

\section{Metode}

Pemberian pelatihan yang memiliki tema "Penerapan Video Promosi Menggunakan Aplikasi Filmora Kepada Peternak Kambing di Malang" dapat menjadi salah satu strategi baru yang mungkin dijalankan para peternak kambing pada era new normal saat ini. Kegiatan Pelatihan tersebut dilakukan dalam bentuk tutorial yang disampaikan secara langsung oleh pemateri. Pelatihan ini dilaksanakan setiap hari sabtu dimulai pada tanggal 19 Juni 2020 pk. 10.00 s/d 11.00 di Institut Teknologi dan Bisnis Asia Malang di Jl. Soekarno Hatta-Rembuksari No. 1A. Pemberi materi adalah tim pengabdian masyarakat yaitu dosen Institut Teknologi dan Bisnis Malang.

Latar belakang keilmuan yang dimiliki oleh masing-masing dosen berasal dari berbagai macam disiplin ilmu yang dapat menunjang semakin berkembangnya bisnis dari peternak kambing dimalang. Dimana disiplin ilmu yang dimiliki diantaranya di bidang pemasaran digital, sumber daya manusia, dan akutansi. Pelatihan pembuatan video promosi dipilih berdasarkan diskusi antara tim pengabdi terhadap mitra pembinaan terhadap kebiasaan dan kebutuhan mereka melakukan promosi melalui dunia online. Sehingga dihasilkan pelatihan pembuatan video 
promosi karena menurut pengusaha ternak kambing, melalui video dapat memberikan penjelasan yang lebih detail dari produk yang dijual oleh masingmasing peternak.

\section{Hasil}

Melalui konsep kegiatan "Penerapan Video Promosi Menggunakan Aplikasi Filmora Kepada Peternak Kambing di Malang" , yang dilakukan dalam bentuk tutorial secara online melalui aplikasi Zoom oleh pemateri, dimana berdasarkan hasil pengabdian ini, para pengusaha ternak kambing di Malang sangat tertarik dan bersemangat untuk mengikuti kegiatan serupa untuk pengembangan ilmu bisnis mereka. Beberapa dari para peserta pelatihan telah mengaplikasikan pelatihan yang diberikan dengan membuat video singkat yang telah di edit secara menarik dan sudah di upload melali media sosial yang dimiliki seperti Facebook.

\section{Diskusi}

Melalui pelatihan ini, tim pengabdi memandang sebagai hal yang penting, karena bagaimanapun pelatihan dan pendidikan masih punya peran penting bagi perkembangan diri seorang pelaku usaha (Morrish, 2011). Memang masih terjadi perdebatan tentang bagaimana wirausaha sebenarnya, terlahir sebagai wirausaha atau belajar menjadi wirausaha (Gouveia, Dinis, do, Ferreira, \& Raposo, 2012).

Namun terlepas perdebatan di atas, secara garis besar, video promosi berperan penting karena terbukti bisa meningkatkan volume penjualan dari sebuah bisnis (Satriawan, 2018), semakin menarik video promosi yang dibuat maka akan semakin efektif meningkatkan volume penjualan. Filmora sendiri berbeda dari softwaresoftware lainnya. Memang software ini lebih simpel dibandingkan Vegas Pro dan sejenisnya, serta tidak memiliki banyak opsi editing yang lebih Professional. Filmora, yaitu Wondershare Video Editor, sudah menanamkan konsep simpel dan berkualitas, serta banyak digunakan untuk edit video, dan itu yang diwariskan ke Filmora. Perbedaannya, Filmora memiliki 2 (dua) mode di saat awal-awal penggunaan, yaitu 
Easy Mode dan Full Feature Mode dimana pada Easy Mode kamu tinggal memilih tema/template, teks intro, video serta gambar yang ingin kamu masukkan, background musik, serta teks penutup.

\section{Kesimpulan}

Berdasarkan hasil kegiatan pengabdian pada masyarakat yang dilakukan bagi peternak kambing di Malang yang telah dilakukan maka dapat disimpulkan sebagai berikut ; A. Belajar dengan aplikasi langsung mampu meningkatkan semangat pengusaha dalam melakukan editing video. B. Menambah softskills para peternak kambing. C. Meningkatkan rasa percaya diri para peternak dengan kemampuan yang dimilikinya.

\section{Pengakuan/Acknowledgements}

Ucapan terima kasih kami haturkan kepada pihak-pihak yang sudah membantu mensukseskan kegiatan program pengabdian masyarakat ini. Kepada anggota tim dosen pengabdian masyarakat, mahasiswa panitia, pihak kampus Institut Asia Malang, dan tentunya pihak peserta yaitu perwakilan peternak kambing di Malang, khususnya kepada Bapak Yoedividianto yang sudah telah mewujudkan sampai terlaksananya pelatihan ini. Serta terikasih kepada peserta pelatihan, dan kepada pihak-pihak yang tidak bisa kami sebutkan satu persatu, yang ikut membantu sehingga pelatihan ini agar berjalan lancar.

\section{Daftar Referensi}

Gouveia, R., Dinis, A., do, A., Ferreira, J., \& Raposo, M. (2012). The Effect of an Entrepreneurial Training Programme on Entrepreneurial Traits and Intention of Secondary Students. Entrepreneurship - Born, Made and Educated, (March). https://doi.org/10.5772/35302

Lupito, Ashaq, 2019, "Kabupaten Malang Jadi Kiblat Ternak Kambing, Populasinya Mencapai 253 Ribu Ekor", artikel pada : Jatimtimes.com, diakses pada 15 Juli 2020 di : https://jatimtimes.com/baca/186654/20190123/210200/kabupatenmalang-jadi-kiblat-ternak-kambing-populasinya-mencapai-253-ribu-ekor 
Morrish, S. C. (2011). Entrepreneurial marketing: A strategy for the twenty-first century? Journal of Research in Marketing and Entrepreneurship, 13(2), 110119. https://doi.org

Satriawan, Robby, 2008, Pengaruh Promosi Terhadap Volume Penjualan Pada Kangaroo Motor Mandiri, Skripsi Dari Fakultas Ekonomi Dan Bisnis Islam Institut Agama Islam Negeri lain Bengkulu, dapat diakses pada : http://repository.iainbengkulu.ac.id/610/1/Robby\%20Satriawan.pdf 